\title{
Water quality assessment of the Sinos River - RS, Brazil
}

\author{
C. Steffens ${ }^{a}$, C. R. Klauck ${ }^{a *}$, T. Benvenuti ${ }^{b}$, L. B. Silva ${ }^{a}$ and M. A. S. Rodrigues ${ }^{a}$ \\ aPrograma de Pós-graduação em Qualidade Ambiental, Universidade Feevale - FEEVALE, RS 239, 2755, \\ Vila Nova, Novo Hamburgo, RS, Brazil

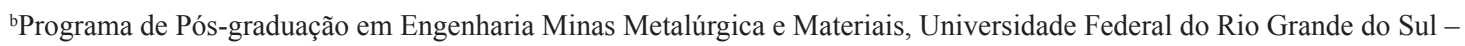 \\ UFRGS, Av. Bento Gonçalves, 9500, Porto Alegre, RS, Brazil \\ *e-mail: claudiark@feevale.br
}

Received: January 17, 2015 - Accepted: May 20, 2015 - Distributed: November 30, 2015

(With 2 figures)

\begin{abstract}
Worldwide environmental pollution is increasing at the same rate as social and economic development. This growth, however, is disorganized and leads to increased degradation of water resources. Water, which was once considered inexhaustible, has become the focus of environmental concerns because it is essential for life and for many production processes. This article describes monitoring of the water quality at three points along the Sinos River (RS, Brazil), one in each of the upper, middle and lower stretches. The points were sampled in 2013 and again in 2014. The water samples were analyzed to determine the following physical and chemical parameters plus genotoxicity to fish: metals ( $\mathrm{Cr}, \mathrm{Fe}, \mathrm{Al})$, chemical oxygen demand, biochemical oxygen demand, chlorides, conductivity, total suspended solids, total phosphorous, total and fecal coliforms, $\mathrm{pH}$, dissolved oxygen, turbidity, total Kjeldahl nitrogen nitrate and ammoniacal nitrogen. Genotoxicity was tested by exposing individuals of the species Astyanax jacuhiensis to water samples and then comparing them with a control group exposed to water from the public water supply. The results confirmed the presence of substances with genotoxic potential at the sample points located in the middle and lower stretches of the river. The results for samples from the upper stretch, at P1, did not exhibit differences in relation to the control group. The physical and chemical analyses did not detect reductions in water quality in the lower stretch, as had been expected in view of the large volumes of domestic and industrial effluents discharged into this part of the river.
\end{abstract}

Keywords: Sinos River, water quality, genotoxicity.

\section{Qualidade da água do Rio dos Sinos - RS, Brasil}

\section{Resumo}

A poluição ambiental aumenta mundialmente, no mesmo ritmo que o desenvolvimento social e econômico. Este crescimento é, muitas vezes, desorganizado e proporciona um aumento da degradação dos recursos hídricos. Água, que já foi considerado inesgotável, tornou-se o foco das preocupações ambientais, pois é essencial para a vida e para muitos processos de produção. Este artigo aborda o monitoramento da qualidade da água, em três pontos do Rio dos Sinos, compreendendo o trecho superior, médio e inferior. Os pontos foram monitorados entre 2013 e 2014. As amostras de água foram analisadas para determinar os parâmetros físico-químicos complementarmente a genotoxicidade em peixes: metais ( $\mathrm{Cr}, \mathrm{Fe}, \mathrm{Al})$, demanda química de oxigenio, demanda bioquímica de oxigênio, cloretos, condutividade, sólidos suspensos totais, fósforo total, coliformes totais e fecais, $\mathrm{pH}$, oxigênio dissolvido, turbidez, nitrogênio total Kjeldahl, nitrato e nitrogênio amoniacal. A avaliação de genotoxicidade foi conduzida pela exposição à água de diferentes pontos do rio de indivíduos da espécie Astyanax jacuhiensis. O grupo controle foi exposto à água de abastecimento público. Os resultados confirmam a presença de substâncias com potencial genotóxico nos pontos localizados nos trechos médio e inferior. No trecho superior, ponto 1, não houve diferenças em relação ao grupo controle. A diminuição da qualidade da água do trecho inferior quando comparada com o superior também foi confirmada através das análises físico-químicas, as quais indicaram uma redução na qualidade da água nos trechos inferiores, como o esperado devido ao grande escoamento de esgotos domésticos e industriais neste trecho do rio.

Palavras-chave: Rio dos Sinos, qualidade da água, genotoxicidade.

\section{Introduction}

The disorganized growth of Brazilian cities is degrading the country's water resources. Discharge of domestic and industrial effluents into water bodies has a significant impact on aquatic communities, caused by continuous exposure to contaminants (Flores-Lopes and Malabarba, 2007).

The Sinos River is an important river that flows through the Metropolitan region of Brazil's southernmost state, 
Rio Grande do Sul. Along the banks of the river, there are high-density settlements and a large cluster of leather goods and footwear manufacturers. The Sinos River is being polluted by both domestic wastes and effluents and is the fourth most polluted river in the whole of Brazil. In November 2006, these discharges were responsible for a terrible environmental accident which killed approximately 86 tons of fish (FEPAM, 2011).

This scenario of growing environmental concerns and environmental pressures highlights the importance of programs to monitor the water quality in the Sinos River and its affluents (Figueiredo et al., 2010; Bieger et al., 2010; Spilki and Tundisi, 2010). Environmental monitoring, whether qualitative or quantitative, is an excellent tool for maintenance of natural ecosystems (Lam, 2009; Matsuura, 2000). Physical and chemical parameters are used to calculate water quality indexes, but these are not alone sufficient to fully characterize the full water quality profile because they cannot provide information about possible interactions between contaminants and the environment or their effects on the environment. Monitoring with living organisms is one option for enhancing the picture painted by physical and chemical variables. It is possible to assess the toxic effects of pollutants in aquatic environments by observing the morphological or physiological changes that organisms exhibit in response to the water quality to which they are exposed (Silva, 2004).

There are a number of different ways of using biomonitoring to analyze the environmental quality of an ecosystem. Biomarkers of genotoxicity enable the toxic and genotoxic effects on the genetic material of a given organism exposed to a given environment to be analyzed (Silva et al., 2003). Genotoxicity tests are widely used to detect the effects of water-borne pollution at the cellular and molecular levels. The micronuclei test is used to associate the presence of xenobiotics in the environment to DNA abnormalities, indicating contamination of the environment by genotoxic substances. A variety of different types of organisms can be used as bioindicators and, of these, fish species have characteristics that make them excellent experimental models for studying aquatic toxicology (Powers, 1989; Karr, 1981).

This article describes an assessment of the water quality of the Sinos River, based on the results of testing the physical and chemical parameters of water samples from three monitoring points and testing for genotoxicity in fish of the specie Astyanax jacuhiensis exposed to water from the same points.

\section{Material and Methods}

\subsection{Study area}

The Sinos River Hydrographic basin is located in the Northeast of Brazil's southernmost state, Rio Grande do Sul, between the geographical coordinates $29^{\circ} 20^{\prime}$ and $30^{\circ}$ $10^{\prime}$ latitude South and $50^{\circ} 15^{\prime}$ to $51^{\circ} 20^{\prime}$ longitude West. It lies to the North of the Serra Geral, where it borders the upper course of the Caí River. The Caí Valley runs to the West until the two systems join at the Jacuí Delta. To the South is a chain of hills that creates the watershed divide between the Sinos and Gravataí river systems, the second of which contributes to forming the Guaíba hydrographic basin. To the East lies the mountain chain where the Sinos River headspring is located, in the interior of the municipal district of Caraá, at an altitude of around 600 meters (COMITESINOS, 2014).

Samples were collected in October 2013 and April 2014, from three different points along the Sinos River. The sampling points were located one in each of the upper, middle and lower stretches of the river, as described in Table 1.

The upper stretch includes the river's headspring, is around $25 \mathrm{Km}$ long, extending between the elevation of 600 meters dropping to the 60 meters, with a declivity gradient of the order of $0.02 \mathrm{~m} / \mathrm{m}$, and passes through the municipal districts of Caraá, Osório, Canela, Santo Antônio da Patrulha, São Francisco de Paula, Gramado and Riozinho. Relief varies from flat to mildly undulating, which is a landscape that is characteristic of the high plains in the Serra region and along the margins of the internal limit of this stretch there is a build-up of organic material on the surface of the ground.

The middle stretch has a gradient of $0.0005 \mathrm{~m} / \mathrm{m}$ and along its extension of approximately $125 \mathrm{~km}$ it receives water from three important affluents: the Paranhana River, which drains an area of $580 \mathrm{~km}^{2}$, the Rolante River, draining $500 \mathrm{~km}^{2}$, and the Ilha River, which drains a further $330 \mathrm{~km}^{2}$. This stretch is very important to the Sinos River water system because it is responsible for draining a large proportion of the mountainous portion of the basin, where there are high levels of rainfall. This stretch of the river passes through the municipal districts of Araricá, Rolante, Igrejinha, Santa Maria do Herval, Parobé, Nova Hartz, Taquara, Glorinha and Três Coroas. The lower stretch is approximately $50 \mathrm{~km}$ long, with mild to near-nonexistent gradient.

Table 1. Location and identification of monitoring points on the Sinos River.

\begin{tabular}{|c|c|c|}
\hline IDENTIFICATION & GEOGRAPHICAL LOCATION & LOCATION ON RIVER \\
\hline $\mathrm{P} 1$ & S 29॰ 43’ 26”; W 50 16’ 46" & $\begin{array}{l}\text { Close to the headspring - Quebrada/Caraá } \\
\text { Upper Stretch }\end{array}$ \\
\hline $\mathrm{P} 2$ & S $29^{\circ} 41^{\prime} 05^{\prime \prime} ;$ W $50^{\circ} 50^{\prime} 52^{\prime \prime}$ & $\begin{array}{l}\text { Santa Cristina - Below the Rio Paranhana Falls - } \\
\text { Parobé - Middle Stretch }\end{array}$ \\
\hline P3 & S $29^{\circ} 47^{\prime} 53^{\prime \prime} ;$ W $51^{\circ} 11^{\prime} 24^{\prime \prime}$ & $\begin{array}{l}\text { Sapucaia - Close to the Arroio Portão Falls - Lower } \\
\text { Stretch }\end{array}$ \\
\hline
\end{tabular}


Downstream from Campo Bom there are stretches where the gradient is close to zero or even climbs, as is characteristic of rivers on plains, with formation of meanders and sedimentation zones. This stretch of the river passes through the municipal districts of Dois Irmãos, Ivoti, Estância Velha, Cachoeirinha, Gravataí, Sapiranga, Campo Bom, Novo Hamburgo, São Leopoldo, Portão, Capela de Santana, São Sebastião do Caí, Sapucaia do Sul, Esteio, Nova Santa Rita and Canoas, many of which contain large towns and cities. This is the most urbanized stretch of the Sinos River basin. Figure 1 illustrates the monitoring areas along the Sinos River, from where samples were collected.

\subsection{Genotoxicity}

Analysis of genotoxicity was conducted using fish of the species Astyanax jacuhiensis obtained from a local fish farm and acclimatized in advance to the experimental conditions $\left(22^{\circ} \mathrm{C} \pm 1{ }^{\circ} \mathrm{C}\right)$ in aquaria with constant aeration. For the micronuclei test, ten individuals were exposed to undiluted samples of River water for 7 days. A control group was exposed to water from the public water supply. The fish were fed with commercial fish food throughout the treatment. No mortality was observed during the exposures. At the end of the exposure period the fish were killed and peripheral blood collected for slide preparation. After making an incision in the tail, $1 \mu \mathrm{L}$ peripheral blood was collected and treated with Giemsa reagent at $10 \%$ and erythrocytes were viewed under an optical microscope (Magnification $=1000 \mathrm{x})$. A total of 2,000 erythrocytes were counted and the presence of nuclear abnormalities was noted (abnormal nucleus shapes - notched nuclei [TN], blebbed nuclei [BL], lobed nuclei [LB], binucleate cells $[\mathrm{BN}]$ and cells with micronuclei [MN]).

For evaluation of the results, statistical analyses were conducted using SPSS ${ }^{\circledR}$ software to run ANOVA and Tukey's post hoc test, considering treatments that exhibited statistically significant differences with relation to the control group as genotoxic $(p<0.05)$.

\subsection{Physical and chemical analysis}

Physical and chemical identification of samples was conducted at the Universidade Feevale's central analytical laboratory. The following parameters were analyzed: metals ( $\mathrm{Cr}, \mathrm{Fe}, \mathrm{Al}$ ), chemical oxygen demand (COD), biochemical oxygen demand (BOD), chlorides, conductivity, total suspended solids (TSS), total kjeldahl nitrogen (TKN), total phosphorous (TP), total and fecal coliforms, $\mathrm{pH}$, dissolved oxygen (DO), Turbidity, nitrate and ammoniacal nitrogen. The methodologies employed for these tests were as described in the Standard Methods for the Examination of Water and Wastewater (APHA, 2005).

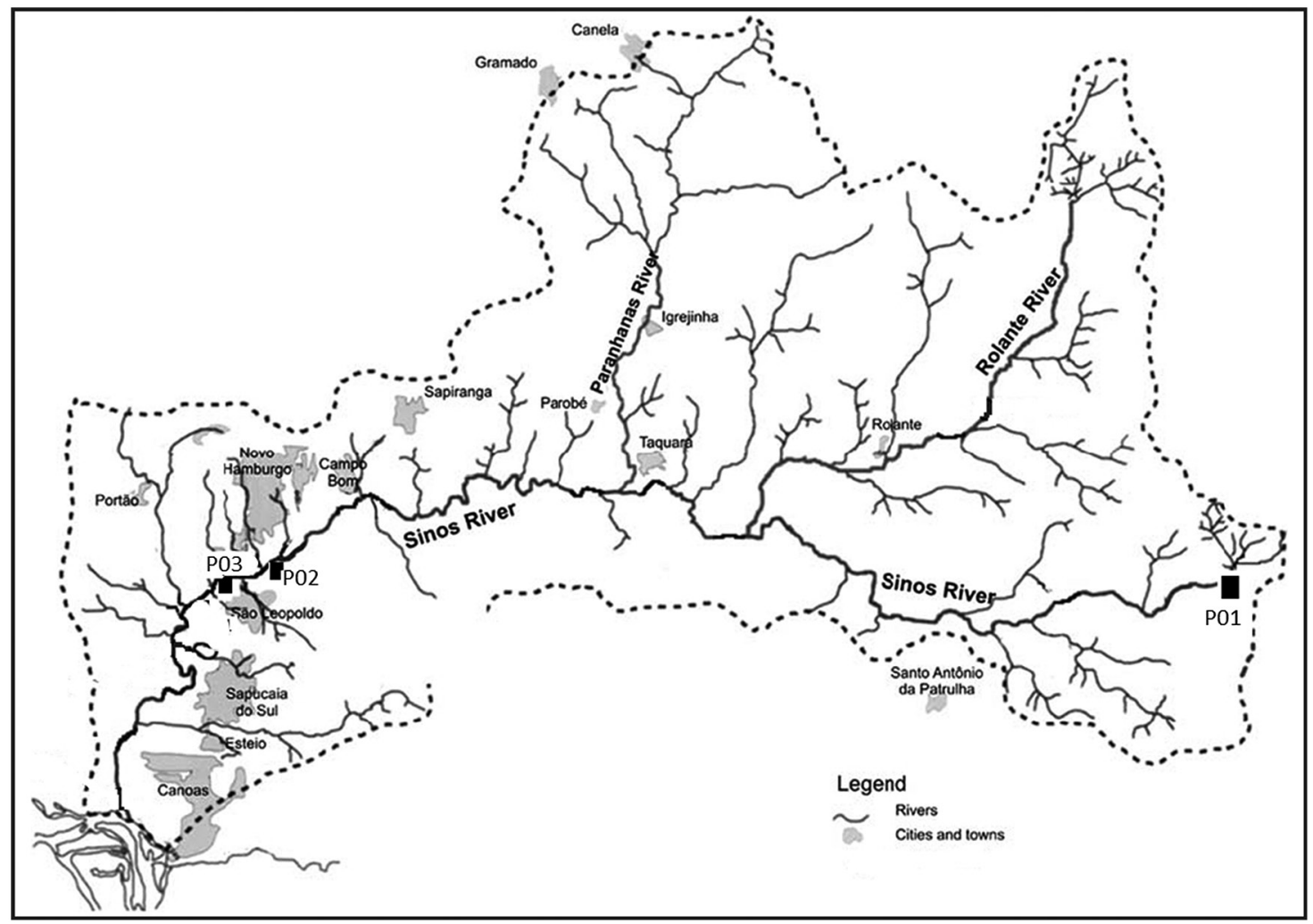

Figure 1. Location of the sampling sites (P01, P02 and P03) in the Sinos River basin study area, South Brazil (Blume et al., 2010). 


\section{Results}

\subsection{Physical and chemical analysis}

The permanent monitoring of water quality aims to increase the knowledge of the quality of superficial water, in order to provide guidance for development of public policies designed to recover the quality of the water in rivers and reservoirs, thereby contributing to sustainable management of water resources. The results of the physical and chemical analyses of water from the three sampling stations are listed in Table 2.

The conductivity result is related to the presence of dissolved ions in the water. The greater the quantity of dissolved ions, the higher the electrical conductivity of the water. Ions that are directly responsible for conductivity readings include potassium, sodium, calcium, carbonates, carbides, sulfates and chlorides. Electrical conductivity does not provide information on which specific ions are present in a water sample, rather it is an indication of the overall quantity of ions in the sample. The parameter indicates possible environmental impacts on the watershed basin, caused by discharge of industrial and mining wastes and other effluents. The results show conductivity increasing from the upper stretch to the lower stretch, indicating possible contamination by discharge of effluents.

The results for phosphorous, aluminum and fecal coliforms in water samples from all points monitored classify the river as class III or IV, even at P1, close to the river's headspring, providing evidence of contamination by anthropic influences. In Brazil, the environmental regulator CONAMA (Conselho Nacional do Meio Ambiente) first classified water quality according to its prevailing types of use in 1986 in Resolution 20a, which was later superseded by Resolution 357 on March 17, 2005 (Brasil, 2005). Sample point P1 is in an area with low population concentration, but intensive agricultural activity, and the results for phosphorous, aluminum and coliforms all indicated concentrations that CONAMA resolution 357/2005 defines as categorizing rivers as class IV. Nitrates are the most common forms of nitrogen associated with water contamination by farming activities. Its contribution to the process of contamination is primarily dependent on climatic conditions, intensity of fertilizer use and management of irrigation. The samples tested from all three points had concentrations below the cut-off for class III rivers, which is set at $10 \mathrm{mg} \mathrm{L}^{-1}$ by CONAMA resolution 357/2005 (Brasil, 2005).

At P2, the concentration of dissolved oxygen in the first sample was greater than in the second, and although it was lower in the second sample, COD remained above $5.0 \mathrm{mg} \mathrm{L}^{-1}$ at P2. It is important to point out that COD should be greater than $4 \mathrm{mg} \mathrm{L}^{-1}$ (Brasil, 2005). The P2 samples were taken from a stretch of the Sinos River with a medium gradient. Of note were the levels of both total and fecal coliforms, which exceeded the limits laid down by CONAMA resolution 357/2005, indicating considerable discharge of domestic sewage into this stretch of the river.

Observing the turbidity result for the 2013 P3 sample, there is a considerable increase over the result for $\mathrm{P} 1$, which can be explained by a period of very heavy rainfall which could have caused erosion along the river, since this is a phenomenon that increases turbidity. This parameter was over the permitted limit, which is 100 NTU according to CONAMA resolution 357/2005 (Brasil, 2005). Turbidity had returned to normal at the second sample collection in 2014. The result for suspended solids was greatly increased at $\mathrm{P} 3$ compared to $\mathrm{P} 1$ and $\mathrm{P} 2$.

Comparing the results of the physical and chemical analyses conducted for this study with results from the same sample points published by Blume et al. (2010), it

Table 2. Results for physical and chemical parameters of water from sampling points P1, P2 and P3.

\begin{tabular}{|c|c|c|c|c|c|c|c|}
\hline \multirow{2}{*}{ Parameter } & \multirow{2}{*}{ Units } & \multicolumn{3}{|c|}{2013} & \multicolumn{3}{|c|}{2014} \\
\hline & & P1 & $\mathbf{P 2}$ & P3 & P1 & $\mathbf{P 2}$ & P3 \\
\hline Chlorides & $\mathrm{mg} \mathrm{L}^{-1}$ & 7.0 & 3.6 & 3.0 & 2.6 & 7.8 & 10.4 \\
\hline Conductivity & $\mu \mathrm{S} \mathrm{cm} \mathrm{cm}^{-1}$ & 45.2 & 62.1 & 103.8 & 29.2 & 71.1 & 111.1 \\
\hline BOD $_{5}$ & $\mathrm{mg} \mathrm{O}_{2} \mathrm{~L}^{-1}$ & 19.0 & $<5.0$ & $<5.0$ & $<5.0$ & $<5.0$ & 8.0 \\
\hline COD & $\mathrm{mg} \mathrm{O}_{2} \mathrm{~L}^{-1}$ & 29.7 & 18.5 & 23.6 & 8.1 & 21.3 & 27.6 \\
\hline Total phosphorous & $\mathrm{mg} \mathrm{L}^{-1}$ & 0.2 & 0.1 & 0.0 & 0.1 & 0.2 & 0.3 \\
\hline Nitrate & $m g L^{-1}$ & 0.4 & 0.1 & 0.4 & 0.1 & 0.2 & 0.3 \\
\hline Ammoniacal nitrogen & $\mathrm{mg} \mathrm{L}^{-1}$ & n.d. & n.d. & n.d. & n.d. & n.d. & n.d. \\
\hline Total Kjeldahl Nitrogen & $\mathrm{mg} \mathrm{L}^{-1}$ & 1.9 & 1.1 & 1.9 & n.d. & n.d. & n.d. \\
\hline Dissolved Oxygen & $\mathrm{mg} \mathrm{O}_{2} \mathrm{~L}^{-1}$ & 5.7 & 8.1 & 6.8 & 9.1 & 7.0 & 4.3 \\
\hline pH & - & 7.1 & 7.5 & 7.1 & 6.9 & 7.4 & 7.0 \\
\hline Total S. Solids & $\mathrm{mg} \mathrm{L}^{-1}$ & 19.4 & 7.8 & 102.6 & n.d. & 8.6 & 21.0 \\
\hline Turbidity & NTU & 28.7 & 25.4 & 136.7 & 1.8 & 22.5 & 38.8 \\
\hline Fecal Coliforms Total & $\mathrm{MNP}^{*}$ & $1.7 \times 10^{3}$ & $8.4 \times 10^{3}$ & $2.3 \times 10^{4}$ & $3.0 \times 10^{2}$ & $8.2 \times 10^{4}$ & $8.8 \times 10^{3}$ \\
\hline Coliforms & $\mathrm{MNP}^{*}$ & $3.4 \times 10^{4}$ & $6.1 \times 10^{4}$ & $1.4 \times 10^{5}$ & $7.8 \times 10^{3}$ & $1.2 \times 10^{5}$ & $5.5 \times 10^{4}$ \\
\hline Aluminum & $\mathrm{mg} \mathrm{L}^{-1}$ & 1.7 & 1.2 & 3,8 & n.d. & 0.7 & 1.2 \\
\hline Total Chrome & $\mathrm{mg} \mathrm{L}^{-1}$ & n.d. & n.d. & 0.0 & n.d. & n.d. & n.d. \\
\hline
\end{tabular}

n.d.: not detected. *MNP: Most Probable Number - MNP100 mL ${ }^{-1}$ Escherichia coli. 
Table 3. Observed frequencies of micronuclei (MN) and other nuclear abnormalities* in 1,000 erythrocytes from Astyanax jacuhiensis.

\begin{tabular}{|c|c|c|c|c|c|c|c|}
\hline & $\mathbf{n}$ & MN & NT & LB & BL & $\mathbf{B N}$ & $\begin{array}{c}\text { Total } \\
\text { abnormalities }\end{array}$ \\
\hline Control & 11 & $0.00 \pm 0.00$ & $0.05 \pm 0.15^{\mathrm{a}}$ & $0.18 \pm 0.25$ & $0.00 \pm 0.00^{\mathrm{a}}$ & $0.00 \pm 0.00^{\mathrm{a}}$ & $0.23 \pm 0.34^{\mathrm{a}}$ \\
\hline P1 & 10 & $0.00 \pm 0.00$ & $0.35 \pm 0.34^{\mathrm{ab}}$ & $0.40 \pm 0.39$ & $0.00 \pm 0.00^{\mathrm{a}}$ & $0.00 \pm 0.00^{\mathrm{a}}$ & $0.75 \pm 0.49^{\mathrm{ab}}$ \\
\hline $\mathrm{P} 2$ & 9 & $0.11 \pm 0.22$ & $0.39 \pm 0.99^{\mathrm{ab}}$ & $0.72 \pm 0.83$ & $0.39 \pm 0.55^{b}$ & $0.28 \pm 0.44^{\mathrm{b}}$ & $1.78 \pm 2.53^{b}$ \\
\hline P3 & 10 & $0.05 \pm 0.16$ & $0.90 \pm 0.88^{\mathrm{b}}$ & $0.35 \pm 0.53$ & $0.15 \pm 0.34^{\mathrm{ab}}$ & $0.20 \pm 0.26^{\mathrm{ab}}$ & $1.60 \pm 1.20^{\mathrm{b}}$ \\
\hline $\mathrm{P}$ & & 0.21 & $0.047 * *$ & 0.17 & $0.028 * *$ & $0.032 * *$ & $0.039 * *$ \\
\hline
\end{tabular}

*Nuclear abnormalities: notched (NT), blebbed (BL), lobed (LB), binucleate (BN) and micronuclei (MN). **Results followed by the same letter are not significantly different.
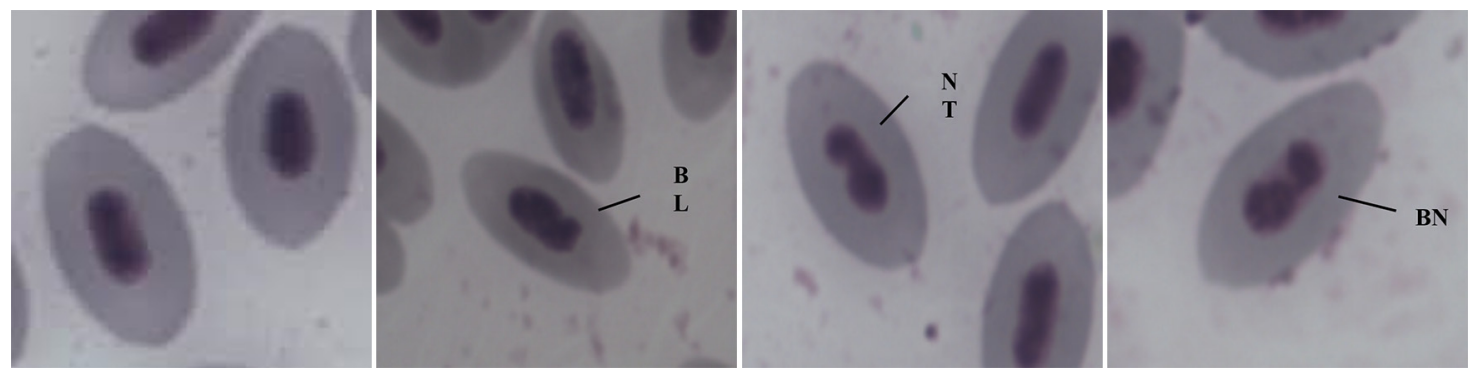

Figure 2. From left to right, erythrocyte with normal appearance, BL: blebbed nucleus, TN: notched nucleus and BN: binucleate erythrocyte.

was observed that the water quality at $\mathrm{P} 1$ had deteriorated. This evidence of increased degradation is of concern because this sampling point is located high up the river. No significant changes in comparison with Blume et al. (2010) results were observed in the physical or chemical parameters analyzed at points $\mathrm{P} 2$ and $\mathrm{P} 3$.

\subsection{Genotoxicity}

Table 3 lists the results for the genotoxicity analysis, showing that none of the groups exhibited differences in terms of micronuclei $(\mathrm{MN})$ numbers when compared with the control group. However, differences were observed in numbers of other nuclear. Figure 2 shows examples illustrating the types of abnormalities observed in cells. For example, there were differences in the number of notched nuclei (NT) among individuals exposed to water samples from $\mathrm{P} 3$ and there were also significant increases in the numbers of blebbed (BL) and binucleate (BN) nuclei in individuals exposed to water from P2. Taking all of the nuclear abnormalities counted together, significant differences were observed between individuals exposed to water from P2 and P3 and those in the control group.

\section{Discussion}

In general, $\mathrm{P} 1$ exhibited better water quality than points P2 and P3, both of which had degraded quality. On the basis of the results observed, it can be stated that although the headspring (P1) is not subject to heavy population density and, as a result, domestic and industrial sewage discharge, some of the water quality parameters were nevertheless elevated. This can be explained by the local farming activity which, in addition to animal manure, also employs agrochemicals. The results of the micronuclei test did not indicate genotoxicity at P1, but a study conducted in 2008 by Scalon et al. (2013) demonstrated that there are substances with genotoxic potential at P1 using the comet assay with fish, which is a test that provides evidence of damage caused by substances that is still possible to repair, i.e. recent damage. In contrast, the micronuclei test is to detect irreparable DNA damage, i.e., damage that alters cell function to an extent that repair mechanisms are unable to correct.

Despite the absence of micronuclei, the genotoxicity results published by Scalon et al. (2013) indicate that fish exposed to the water at P1 are subject to conditions of environmental stress. The increased numbers of abnormalities at P2 and P3 can be explained by build up of pollutants, which run downstream and accumulate; and locations close to discharges in either greater volume or higher concentrations, primarily caused by human activities in the vicinity. The primary sources of pollution are densely populated urban areas, with a very diverse range of activities including production of food, petrochemicals, timber yards and furniture making, metalwork and mechanical engineering, and production of leather, leather goods and footwear. The low water quality in the middle and lower stretches of the river is of great concern because these parts of the basin are the most urbanized and it is from this part of the river that water is taken for the public water supplies of the surrounding towns and cities. Conventional technology is employed to treat the drinking water supply in this area, in other words coagulation-flocculation/filtration, and these operations are not very efficient at removing several types of contaminants from water 


\section{Conclusions}

The current state of the water quality in the hydrographic basin of the Sinos River did not exhibit any major changes in comparison with studies undertaken using the same sample points in 2010. The results continue to show that the river's water quality deteriorates along its course, primarily due to increasing urbanization. However, the results of analyses conducted on samples collected in 2013 and 2014 were different for some parameters, demonstrating that permanent monitoring of the Sinos River's water quality is indispensable.

\section{Acknowledgements}

The researchers would like to thank the following Brazilian research funding agencies for providing financial support: Fapergs, FINEP, CNPq, and Capes.

\section{References}

AMERICAN PUBLIC HEALTH ASSOCIATION - APHA, 2005. Standard methods for the examination of water and wastewater. 21st ed. Washington.

BIEGER, L., CARVALHO, A.B.P., STRIEDER, M.N., MALTCHIK, L. and STENERT, C., 2010. Are the streams of the Sinos River basin of good water quality? Aquatic macroinvertebrates may answer the question. Brazilian Journal of Biology $=$ Revista Brasileira de Biologia, vol. 70, no. 4, suppl., pp. 1207-1215. http:// dx.doi.org/10.1590/S1519-69842010000600010. PMid:21225162.

BLUME, K.K., MACEDO, J.C., MENEGUZZI, A., SILVA, L.B., QUEVEDO, D.M. and RODRIGUES, M.A., 2010. Water quality assessment of the Sinos River, Southern Brazil. Brazilian Journal of Biology $=$ Revista Brasileira de Biologia, vol. 70, no. 4, suppl., pp. 1185-1193. http://dx.doi.org/10.1590/S151969842010000600008. PMid:21225160.

BRASIL. Conselho Nacional do Meio Ambiente - CONAMA, 2005 [viewed 25 November 2014]. Resolução CONAMA n ${ }^{\circ} 357$, de 17 de março de 2005. Dispõe sobre a classificação dos corpos de água e diretrizes ambientais para o seu enquadramento, bem como estabelece as condições e padrões de efluentes, e dá outras providencias. Diário Oficial da República Federativa do Brasil [online], Brasilia, 18 mar. pp. 58-63. Available from: http://www. mma.gov.br/port/conama/res/res05/res35705.pdf
COMITÊ DE GERENCIAMENTO DA BACIA HIDROGRÁFICA DO RIO DOS SINOS - COMITESINOS, 2014 [online]. [viewed 30 August 2014]. Available from: http://www.comitesinos.com.br

FIGUEIREDO, J.A.S., DRUMM, E., RODRIGUES, M.A.S. and SPILKI, F.R., 2010. The Rio dos Sinos watershed: an economic and social apace and its interface with environmental status. Brazilian Journal of Biology = Revista Brasileira de Biologia, vol. 70, no. 4, suppl., pp. 1131-1136. PMid:21225153.

FLORES-LOPES, F. and MALABARBA, L.R., 2007. Revisão de alguns aspectos de assembléia de peixes utilizada em programas de monitoramento ambiental. Vitalle, vol. 19, no. 1, pp. 45-58.

FUNDAÇÃO ESTADUAL DE PROTEÇÃO AMBIENTAL HENRIQUE LUIZ ROESSLER - FEPAM, 2011 [viewed 23 August 2013]. Qualidade das águas da bacia hidrográfica do Rio dos Sinos [online]. Porto Alegre. Available from: http://www. fepam.rs.gov.br/qualidade/qualidade_sinos/sinos.asp

KARR, J.R., 1981. Assessment of biotic integrity using fish communities. Fisheries, vol. 6, no. 6, pp. 21-27. http://dx.doi. org/10.1577/1548-8446(1981)006<0021:AOBIUF>2.0.CO;2.

LAM, P.K.S., 2009. Use of biomarkers in environmental monitoring. Ocean and Coastal Management, vol. 53, no. 7, pp. 348-354. http://dx.doi.org/10.1016/j.ocecoaman.2009.04.010.

MATSUURA, K., 2000. Bioindicadores em ecossistemas. Brasília: Unesco.

POWERS, D.A., 1989. Fish as model systems. Science, vol. 246, no. 4928, pp. 352-358. http://dx.doi.org/10.1126/science.2678474. PMid:2678474.

SCALON, M.C.S., RECHENMACHER, C., SIEBEL, A.M., KAYSER, M.L., RODRIGUES, M.T., MALUF, S.W., RODRIGUES, M.A.S. and SILVA, L.B., 2013. Genotoxic potencial and physicochemical parameters of Sinos River, sothern Brasil. The Scientific World Journal, vol. 2013, pp. 1-6. http://dx.doi.org/10.1155/2013/209737.

SILVA, A.G., 2004. Alterações histopatológicas de peixes como biomarcadores da contaminação aquática. Londrina: Universidade Estadual de Londrina, 80 p. Masters Dissertation.

SILVA, J., HEUSER, V. and ANDRADE, V., 2003. Biomonitoramento ambiental. In: J. SILVA, B. ERDTMANN and J. HENRIQUES, eds. Genética toxicológica. Porto Alegre: Alcance.

SPILKI, F.R. and TUNDISI, J.G., 2010. Priority targets for environmental research in the Sinos River basin. Brazilian Journal of Biology $=$ Revista Brasileira de Biologia, vol. 70, no. 4, suppl., pp. 1245-1247. http://dx.doi.org/10.1590/S151969842010000600014. PMid:21225166. 